\title{
Relative impacts of key drivers on the response of the water table to a major alley farming experiment
}

\author{
S. L. Noorduijn ${ }^{1,2}$, K. R. J. Smettem ${ }^{2}$, R. Vogwill ${ }^{3}$, and A. Ghadouani ${ }^{1}$ \\ ${ }^{1}$ Aquatic Ecology and Ecosystem Studies, School of Environmental Systems Engineering, The University of Western \\ Australia, 35 Stirling Highway, Crawley, Western Australia, 6009, Australia \\ ${ }^{2}$ Center for Ecohydrology, School of Environmental Systems Engineering, The University of Western Australia, \\ 35 Stirling Highway, Crawley, Western Australia, 6009, Australia \\ ${ }^{3}$ Department of Environment and Conservation, Locked Bag 104, Bentley Delivery Centre, Bentley, \\ Western Australia, 6983, Australia
}

Received: 3 June 2009 - Published in Hydrol. Earth Syst. Sci. Discuss.: 23 June 2009

Revised: 15 October 2009 - Accepted: 16 October 2009 - Published: 5 November 2009

\begin{abstract}
Widespread clearing of native vegetation in Southwest Western Australia has led to land degradation associated with rising groundwater, secondary salinisation and waterlogging. Re-establishing deep-rooted perennial vegetation across parts of the landscape is one technique for managing land degradation. Alley farming is an agroforestry practice where multiple perennial tree belts are planted in alternation with traditional agricultural crops. To identify the best configuration (belt width versus alley width) for controlling rising groundwater levels and providing viable economic returns, a large scale experiment was established in 1995. The experiment contains seven different alley farming designs, each with transects of piezometers running across tree belts into adjacent alleys to monitor changes in the groundwater level. Two control piezometers were also installed in an adjacent paddock. Groundwater at the site is shallow $(<3 \mathrm{~m})$ and of poor quality (pH3-5, Ec $2.1-45.9 \mathrm{mS} \mathrm{cm}^{-1}$ ) so root water uptake from the saturated zone is limited.

Simple hydrograph analysis could not separate treatment effects on the water table response. Subsequent statistical analysis revealed that $20-30 \%$ of the variability in the water table data over the 12 year study period was attributable to the alley farming experiment. To futher investigate the effect of the experiment on groundwater response, additional hydrograph analysis was conducted to compare the trends in the control piezometers in relation to those located within the belts. A difference of $0.9 \mathrm{~m}$ was observed between the mean groundwater levels in the control piezometers and the mean
\end{abstract}

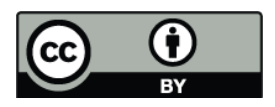

Correspondence to: A. Ghadouani (anas.ghadouani@uwa.edu.au) levels in the perennial belt piezometers. For a mean specific yield of $0.03 \mathrm{~m}^{3} \mathrm{~m}^{-3}$ (standard deviation of $0.03 \mathrm{~m}^{3} \mathrm{~m}^{-3}$ ) this equates to an additional average annual water use of $27 \mathrm{~mm} \mathrm{yr}^{-1}$ (standard deviation of $33 \mathrm{~mm} \mathrm{yr}^{-1}$ ) by the perennial agroforestry system. It is concluded that declining annual rainfall is the principal control on hydrograph response at the site, whilst perennial biomass development has a lesser impact on water table depth.

\section{Introduction}

Secondary dryland salinity is a result of the combined effects of groundwater rise and mobilisation of soil profile salt store (Scott and Sudmeyer, 1993; Nulsen and Baxter, 1986; Asseng et al., 2001a; Asseng et al., 2001b). This form of land degradation affects a global area of more than 33 million ha (FAO-AGL, 2000). Approximately 4.6 million ha of agricultural land in Australia experiences the negative impacts of dryland salinity (National Land and Water Resources Audit, 2001; George and Bennett, 2001). The causal mechanism is the different water use regimes and shallower rooting depths of introduced agricultural crops compared to native species (Clarke et al., 2002; Ferdowsian et al., 1996). Seasonal water use by annual agricultural crops and reduced ability to utilise water from deeper in the soil profile leads to an increase in recharge (Scott and Sudmeyer, 1993; Asseng et al., 2001b; Eastham and Gregory, 2000). The development and successful implementation of natural resource management strategies to improve ecosystem health and remediation of degraded land relies on a quantitative understanding of these changes to the water cycle (Kareiva and Marvier, 2003).

Published by Copernicus Publications on behalf of the European Geosciences Union. 
The reintroduction of native woody perennial species is one management option for controlling groundwater rise by increasing evapotranspiration (Bari et al., 1996; Langford, 1976; Ruprecht and Stoneman, 1993) and re-establishing a more ecologically sustainable hydrology at catchment scale (Cramer and Hobbs, 2002; Hatton et al., 2003). The proportion of land required for perennial revegetation and the location within the catchment to achieve recharge control is still not entirely resolved. Within Australia, estimates range up to $80 \%$ of the catchment area (George et al., 1997; Bell and Froend, 1990). Recommendations for more targeted local planting originally focused on the zone of recharge (Nulsen, 1984) but recent recommendations have encompassed the entire catchment area (Clarke et al., 1999; George et al., 1991; Salama et al., 1991). The large area of perennial revegetation required to control groundwater recharge implies a loss of agricultural land and this is of economic concern to the farming community. Therefore, agroforestry techniques have generated interest because they can potentially reduce recharge whilst minimising the area of revegetation (Clarke et al., 2002).

The practise of alley farming, or runoff agroforestry, has been promoted as a management option because the system retains agricultural output by planting trees in rows/belts interspersed with conventional food crops (Lefroy and Stirzaker, 1999; Ogunlana et al., 2006; Kang et al., 1984; Droppelmann and Berliner, 2003). Originally initiated to eliminate fallow periods in the African agricultural areas (Kang et al., 1984; Ogunlana et al., 2006), alley farming has been extensively trialled in the rain-fed agricultural regions of Australia. Alley farming has generated environmental outcomes, for example disease and pest control, food sources and habitat for native fauna (Bird et al., 1992; Lefroy et al., 2005; Mooris and Johnson, 1967). The economic potential of perennial alley systems may also be enhanced if they can be developed as greenhouse sinks and sources of biofuel (Harper et al., 2007; Bartle et al., 2007). Research to date has focused on understanding the hydrological functioning of hillslope alley systems (Ellis et al., 2006; Oliver et al., 2005; White et al., 2002; Wildy and Pate, 2002) and the water requirements for successful production in dryland environments (Cooper et al., 2005).

In an attempt to identify the most effective alley farming design for reducing groundwater levels at a lowland valley site, a large replicated experiment was established in 1995. The objective of this experiment was to test the hypothesis that water tables will be lowest under alley farming designs with the greatest biomass per unit area (and hence the greatest leaf area and transpiration). Transects of piezometers were installed across the site to monitor the water table response over a 12 year period after establishment. Simple hydrograph analysis of the 12 year data could not separate treatment effects on the water table response. Using a more complex spatial statistical analysis it was possible to attribute 20 to $30 \%$ of the variability in the water table data set, after the climatic signature was removed, to the impacts of the alley farming experiment (Noorduijn et al., 2009). It was concluded that the impacts of the experiment were being masked by broad scale temporal and spatial trends which account for the remaining $60 \%$ of the variability.

In this study, we further investigate the effects of climate on piezometer hydrograph levels and their response to the alley farming experiment. The objective is to determine the relative contributions of climate trends on the observed changes in the water table depth. In addition, measured perennial biomass has been incorporated to assess the relationship between observed water table decline and perennial belt transpiration. This will help to develop a more complete understanding of the impacts of both rainfall and perennial plant development on groundwater levels, under the alley farming experiment.

\section{Methodology}

\subsection{Site description}

The Toolibin Alley Farming Trial (TAFT) comprises of two field sites (Davenport and Nepowie) within the Natural Diversity Recovery Catchment of Lake Toolibin. The site under investigation is located $8 \mathrm{~km}$ north of Toolibin Lake, Western Australia (Davenport, 32 50'36" South, 117 $38^{\prime} 65^{\prime \prime}$ East). The site has a Mediterranean climate with the majority of rainfall during the winter months (May-Aug, $\sim 60 \%$ ), the remaining months remain comparatively dry and receive between $23-44 \%$ of the annual rainfall. Average pan evaporation is $1800 \mathrm{~mm} \mathrm{yr}^{-1}$ and potential evaporation usually greatly exceeds rainfall from September to April. The average maximum and minimum temperatures for the study site range from $32^{\circ} \mathrm{C}$ to $9^{\circ} \mathrm{C}$ during the summer months (NovApril) and $20^{\circ} \mathrm{C}$ to $5^{\circ} \mathrm{C}$ during the winter months (MayOct) (Bureau of Meteorology, Australia). Water influx to the site from groundwater is comparatively minor due to low hydraulic conductivity of the soils and very low hydraulic gradients (George, 1992).

\subsection{Experimental design}

The study was designed to investigate three independent variables: revegetation density (belt width/alley width), belt width $(\mathrm{m})$, and tree species. Seven different treatment designs (A-F) were applied to the sites in a randomised complete block design (Fig. 1). Each design comprised five tree species, of which the three keys species were Eucalyptus vegrandis, E. occidentalis and Casuarina obesa; for this study only E. vegrandis is considered due to lack of consistent sampling for the remaining two species. Piezometers were installed in each plot on transects orientated perpendicular to the tree belt (within $E$. vegrandis). They were installed to a depth of $3.7 \mathrm{~m}$ with slotted casing for the bottom $2 \mathrm{~m}$. A minimum of two piezometers were installed in each plot, running 
Table 1. Details of Toolibin Alley Farming Experiment at Davenport's site.

\begin{tabular}{ccccccc}
\hline $\begin{array}{c}\text { Treatment } \\
\text { Design }\end{array}$ & Plot & \# Bores & $\begin{array}{c}\text { Belt Width } \\
(\mathrm{m})\end{array}$ & $\begin{array}{c}\text { Alley } \\
\text { Width }(\mathrm{m})\end{array}$ & $\begin{array}{c}\text { Revegetation } \\
\%\end{array}$ & $\begin{array}{c}\text { \# Rows } \\
\text { of Trees }\end{array}$ \\
\hline A & D9 & 3 & 32 & 74 & 30.2 & 5 \\
A & D7 & 3 & 32 & 74 & 30.2 & 5 \\
A & D16 & 5 & 32 & 74 & 30.2 & 5 \\
B & D2 & 3 & 18 & 102 & 15 & 3 \\
B & D15 & 5 & 18 & 102 & 15 & 1 \\
B & D12 & 3 & 18 & 102 & 15 & 3 \\
C & D5 & 3 & 18 & 42 & 30 & 3 \\
C & D17 & 5 & 18 & 42 & 30 & 3 \\
C & D14 & 3 & 18 & 42 & 30 & 3 \\
D & D8 & 3 & 11 & 56 & 16.4 & 2 \\
D & D3 & 3 & 11 & 56 & 16.4 & 2 \\
D & D20 & 5 & 11 & 56 & 16.4 & 2 \\
E & D6 & 2 & 11 & 22.5 & 32.8 & 2 \\
E & D19 & 4 & 11 & 22.5 & 32.8 & 2 \\
E & D13 & 2 & 11 & 22.5 & 32.8 & 1 \\
F & D4 & 2 & 4 & 27.5 & 12.7 & 1 \\
F & D18 & 4 & 4 & 27.5 & 12.7 & 1 \\
F & D10 & 2 & 4 & 27.5 & 12.7 & 1 \\
G & D21 & 3 & 138 & 0 & 100 & block \\
G & D11 & 3 & 138 & 0 & 100 & block \\
G & D1 & 3 & 138 & 0 & 100 & block \\
Control & DC2 & 1 & - & - & - & - \\
Control & DC1 & 1 & - & - & - & - \\
\hline & & & & & &
\end{tabular}

from the centre of the perennial tree belt to the centre of the alley (Table 1). Two control piezometers were installed on the site, to assess the water table response in the adjacent paddock under annual grass. Water table depth was monitored every one to two months for the first three years. Subsequent measurements were sporadic, occurring only once or twice a year. From April 2007 to January 2008 monthly measurements were taken. Agricultural systems in the region of south west Western Australia are rainfed and no additional irrigation was applied at this experiment. No agricultural crops were planted within the alleys over the period of the experiment, although annual cereal crops had been pre-experiment. Some stock were intermittently present, annual grasses and weeds propagated during the wet winter months.

\subsection{Data collection and analysis}

The water table data set was initially recorded as static water level (SWL) depths in meters below ground level (m b.g.l.) and consisted of 74 piezometers monitored on 39 dates (over the period October 1995 to January 2008). Piezometers were excluded where monitoring had been irregular as a result of damage to the piezometer. The remaining 69 piezometers were surveyed to obtain elevations above Australian height datum (m AHD) using a local datum. Due to the extremely low topographic gradient and low hydraulic conductivity, data are presented in the form of $\mathrm{mb.g} .1$. because it is assumed that lateral through flow is minimal. Daily rainfall and meteorological data were obtained for the meteorological station at Corrigin $\left(32.33^{\circ}\right.$ South, $117.87^{\circ}$ East) from the Bureau of Meteorology.

An extensive biomass survey was conducted at the site to assess the growth of the perennial species at 12 years of age. Destructive sampling was conducted for the different belt widths in the experiment; the samples were dried and weighed. The density of surviving stems was comparable between the different belt widths preventing biased results in the above-ground biomass results. 57 individual E. vegrandis trees were sampled for above ground biomass from the different belt width. An allometric correlation was established between stem basal area at $10 \mathrm{~cm}$ and the aboveground biomass for those samples $\left(r^{2}=0.81\right)$, the results of the calculated biomass show a high correlation with the observed values $\left(r^{2}=0.86\right)$. At the site, basal area was recorded for 332 individual $E$. vegrandis trees from which biomass were estimated using the allometric correlation. This enabled good estimates of standing biomass per $\mathrm{m}^{2}$ to be undertaken. 


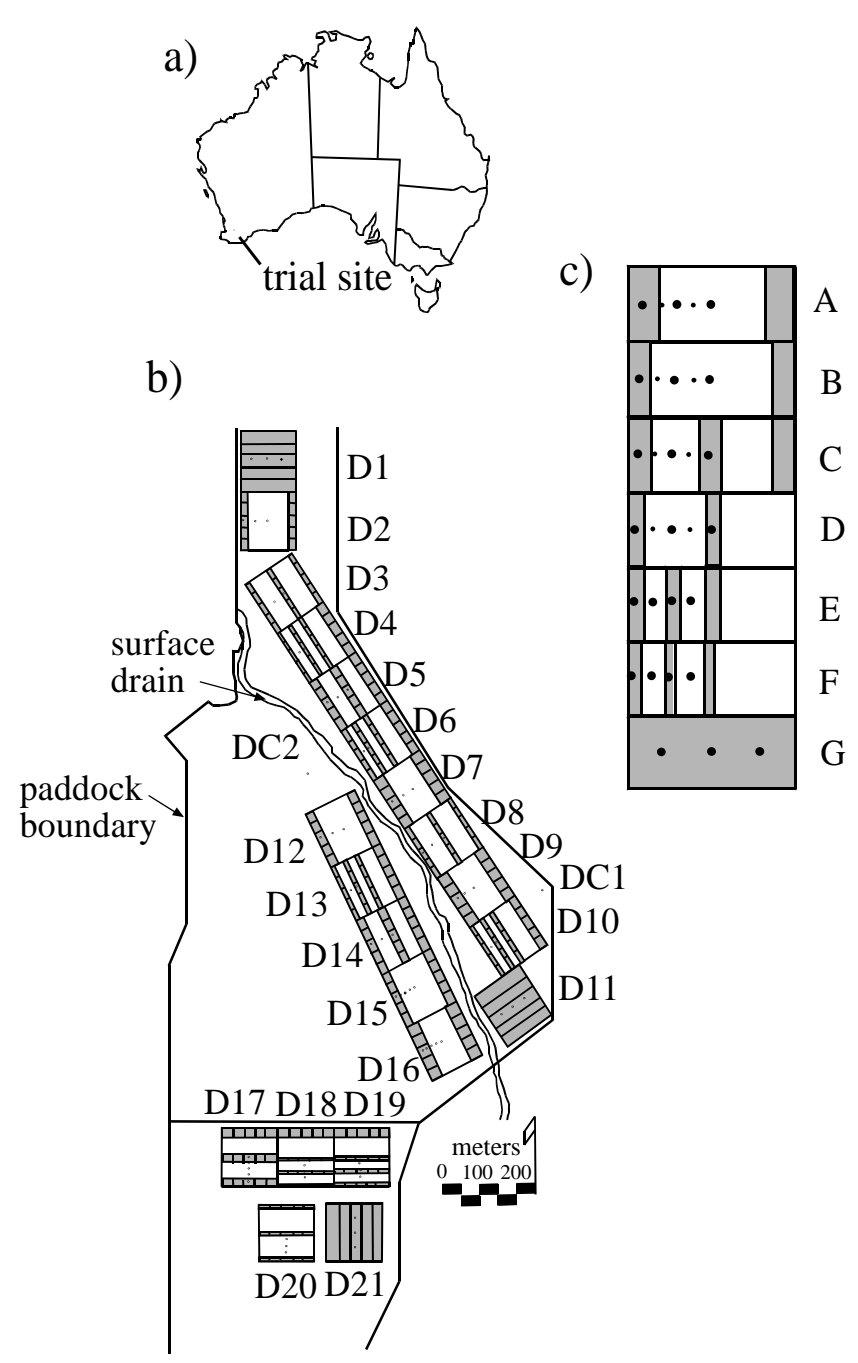

Fig. 1. (a) Location and (b) layout of Davenports experiment site. The location of a surface water drain and paddock boundaries have been identified. (c) shows the conceptual layout of each of the treatment types; the black boxes identify the locations of the experiment plots and the black circles show the locations of the individual piezometers within the plots in the form of a transect.

\section{Results}

\subsection{Regional climate trends}

A significant decrease in both winter and total annual rainfall has been observed in the region over the last century. The observed decline since 1969 is $21 \%$, compared to the period from 1907-1968 (Smith et al., 2000). This decline is shown in Fig. 2 for the Corrigin rainfall data, where the mean monthly rainfall remains equal to or above the mean monthly average from 1910 to 1950 after which the mean monthly rainfall falls below the monthly average for the period of 1910 to 2008 resulting in the observed decline. Over the period of the experiment (1996-2007) the average annual

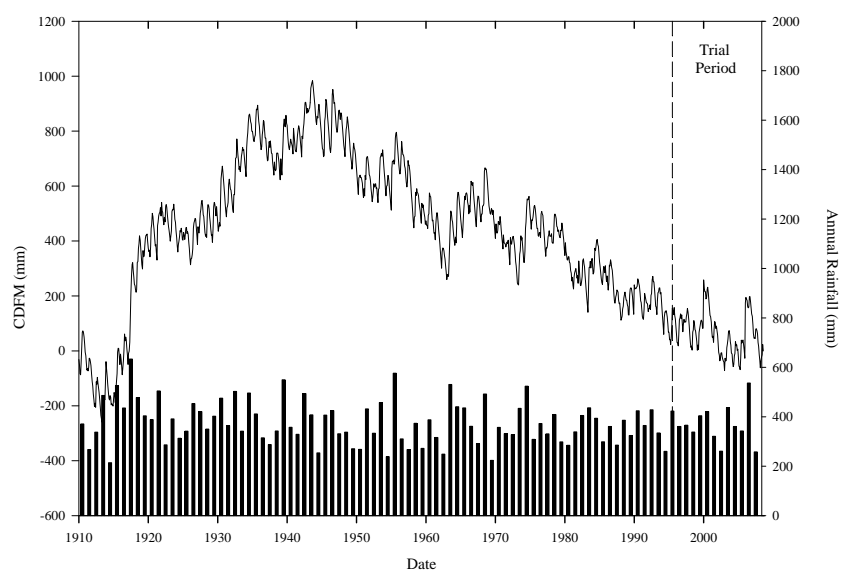

Fig. 2. Cumulative Deviation from the Mean (CDFM) monthly rainfall (line) and total annual rainfall (bars) recorded at Corrigin meteorological station for the period from January 1911 to 2007. The dotted line identifies the start of the experiment.

rainfall was $367 \mathrm{~mm}(\mathrm{SD} \pm 77 \mathrm{~mm})$. The highest annual rainfall for this period occurred in $2006(537 \mathrm{~mm})$ and contained a contribution from one large $(149 \mathrm{~mm})$ out of season rainfall event in January of that year.

The control piezometers can be assumed to reflect the annual climatic effects on water table depth at the site. The departure of the experimental water table depths from the control piezometers provides a measure of the treatment effect. For most years the summer water table depth integrates the effects of the season on water table drawdown. However, in 2006 a large summer storm immediately preceded the piezometer measurements and this is reflected in the water table rise in this summer.

As shown in Table 2, monthly net discharge in 2007 is generally greater in 2007 than in 1996 . This has been estimated by calculating deviation of the minimum $\left(\mathrm{Min}_{\mathrm{dev}}\right)$, maximum $\left(\mathrm{Max}_{\mathrm{dev}}\right)$ and average (Average $\mathrm{dev}_{\mathrm{f}}$ ) water table depth (m b.g.1.) from the control piezometer, allowing for variability in specific yield (Sy). There is also an increase in the range of values, both positive and negative. Estimated minimum values are consistently equal to or higher than those of the control piezometers. The distribution of those piezometers where the groundwater is above that of the control piezometers in 1996 are spread across the experiment, however in 2007 these groundwater levels are found in only two locations: D113 (Apr-July), and D32 (Aug-Jan). Average net monthly recharge ranges between $-15.8 \mathrm{~mm}$ (discharge) to $5.6 \mathrm{~mm}$ (recharge) in 1996, a shift toward net discharge is apparent in $2007(-35.3-2.5 \mathrm{~mm})$.

\subsection{Water Table Fluctuations}

Groundwater levels have declined over the study period. In 1996 the water table was between $0.05-1.82 \mathrm{~m}$ b.g.l. and in 2007 between $0.68-4.15 \mathrm{~m}$ b.g.l. In 1996 the average height 
Table 2. Monthly net recharge (mm). Positive values indicate recharge and negative values indicate discharge. Min, Average, and max relate to the experiment water level deviation from the control piezometer groundwater depth (m b.g.l.). Symin, $\mathrm{Sy}_{\mathrm{av}}$, and $\mathrm{Symax}$ are the minimum, average, and maximum specific yield values at the site.

\begin{tabular}{|c|c|c|c|c|c|c|c|c|c|}
\hline & \multicolumn{3}{|c|}{ Min } & \multicolumn{3}{|c|}{ Average } & \multicolumn{3}{|c|}{ Max } \\
\hline & $S y_{\min }$ & Syav & Symax & $S y_{\min }$ & Syav & $S y_{\max }$ & $\mathrm{Sy}_{\min }$ & Syav & Symax \\
\hline Oct-1995 & 3.7 & 11.1 & 25.9 & 0.8 & 2.4 & 5.6 & -5.8 & -17.4 & -40.6 \\
\hline Dec-1995 & 2.6 & 7.9 & 18.4 & 0.2 & 0.5 & 1.2 & -1.5 & -4.4 & -10.3 \\
\hline Feb-1996 & 2.1 & 6.2 & 14.4 & -0.4 & -1.3 & -3.0 & -4.2 & -12.5 & -29.1 \\
\hline Apr-1996 & 2.7 & 8.0 & 18.6 & -0.3 & -0.9 & -2.0 & -2.7 & -8.0 & -18.6 \\
\hline Jun-1996 & 2.9 & 8.7 & 20.3 & -0.6 & -1.7 & -4.0 & -3.6 & -10.8 & -25.2 \\
\hline Jul-1996 & 1.4 & 4.1 & 9.5 & -1.3 & -3.9 & -9.1 & -11.7 & -35.0 & -81.6 \\
\hline Aug-1996 & 3.3 & 9.9 & 23.1 & 0.4 & 1.1 & 2.5 & -3.2 & -9.6 & -22.4 \\
\hline Sep-1996 & 2.6 & 7.7 & 17.9 & 0.2 & 0.5 & 1.1 & -1.8 & -5.3 & -12.3 \\
\hline Oct-1996 & 1.2 & 3.6 & 8.4 & -0.9 & -2.6 & -6.1 & -3.7 & -11.1 & -25.9 \\
\hline Nov-1996 & 2.2 & 6.6 & 15.4 & -0.2 & -0.5 & -1.3 & -3.0 & -9.0 & -21.0 \\
\hline Dec-1996 & 1.2 & 3.5 & 8.1 & -2.3 & -6.8 & -15.8 & -5.8 & -17.3 & -40.3 \\
\hline Jan-2007 & 2.9 & 8.7 & 20.3 & -5.0 & -15.1 & -35.3 & -17.0 & -51.0 & -119.0 \\
\hline Apr-2007 & 5.9 & 17.6 & 41.0 & -4.7 & -14.2 & -33.1 & -18.1 & -54.2 & -126.4 \\
\hline May-2007 & 3.0 & 9.0 & 21.0 & -4.8 & -14.3 & -33.4 & -13.1 & -39.3 & -91.7 \\
\hline Jun-2007 & 7.4 & 22.1 & 51.5 & -3.6 & -10.7 & -24.9 & -13.3 & -39.8 & -92.8 \\
\hline Jul-2007 & 11.3 & 33.8 & 78.8 & -2.6 & -7.9 & -18.5 & -14.3 & -42.8 & -99.8 \\
\hline Aug-2007 & 6.1 & 18.2 & 42.4 & -4.9 & -14.8 & -34.5 & -18.1 & -54.2 & -126.4 \\
\hline Sep-2007 & 5.2 & 15.6 & 36.4 & -3.8 & -11.4 & -26.6 & -15.4 & -46.2 & -107.8 \\
\hline Oct-2007 & 3.4 & 10.1 & 23.5 & -2.5 & -7.4 & -17.2 & -14.3 & -42.8 & -99.8 \\
\hline Nov-2007 & 3.0 & 8.9 & 20.7 & -3.0 & -9.1 & -21.1 & -14.3 & -42.8 & -99.8 \\
\hline Dec-2007 & 3.2 & 9.5 & 22.1 & -3.0 & -9.1 & -21.2 & -14.7 & -44.0 & -102.6 \\
\hline Jan-2008 & 2.0 & 5.9 & 13.7 & -4.5 & -13.6 & -31.7 & -17.6 & -52.7 & -122.9 \\
\hline
\end{tabular}

of the seasonal fluctuation in water level across the site was $1.24 \mathrm{mb}$ b.g.1. ( $\mathrm{SD} \pm 0.13 \mathrm{~m}$ ). This increased to $1.45 \mathrm{~m}$ b.g.1. $(\mathrm{SD} \pm 0.31 \mathrm{~m})$ in 2007 , which may be attributed to the impacts of vegetation and the variability in treatment types. A general overview of the water table response at the site is shown in Fig. 3. Due to infrequent monitoring, clear seasonal signatures cannot always be identified. However a comparison is made between the winter minimum and summer maximum groundwater depths for all the experimental data with the average summer minima for the control piezometers. The trend observed can be divided into two periods between 1996-2000 a continued rise in the water table heights is observed followed by a subsequent drop from 2000-2002 after which it appears to remain at a constant depth of approximately 2.5 m b.g.l. (Fig. 3). After 2000 the summer (NovApril) minimum water table depths in the experiment were consistently lower than the control piezometers.

Combining all the experimental data and comparing the mean water table level to the mean from the control piezometers shows that the water table in the experiment's piezometers (post 2000) was on average $0.9 \mathrm{~m}$ deeper than in the control piezometers (Fig. 4). This is apparent for all dates on which the piezometers where monitored, irrespective of

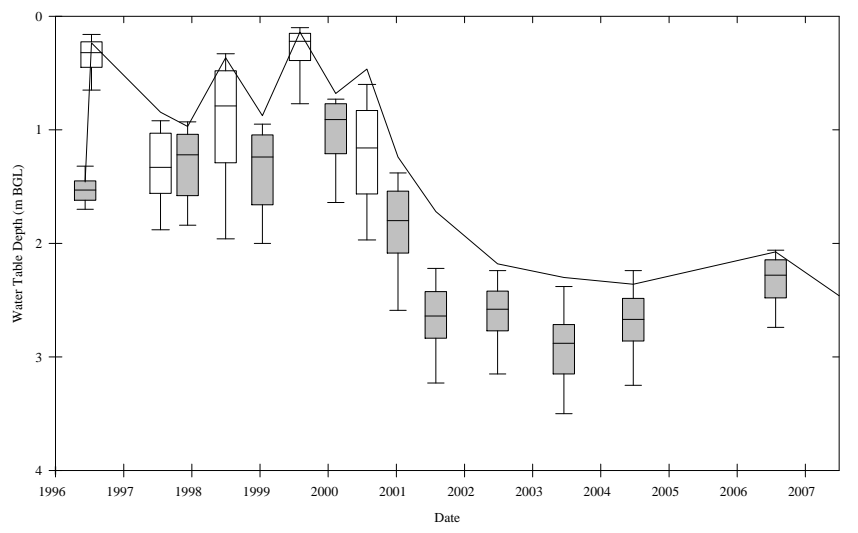

Fig. 3. Box plot of the summer minimum (grey) and winter maximum (white) water table depths (meters below-ground level) over the period of 1995-2008. The boxes represent the mean, 25 percentile, and the 75 percentile. The whiskers indicate the 10 and 90 percentiles. The line represents the average control piezometer response. The absence of winter maximums from 2001 to 2007 is due to the lack of data. 
Average Control Piezometers Water Table Depth (m BGL)

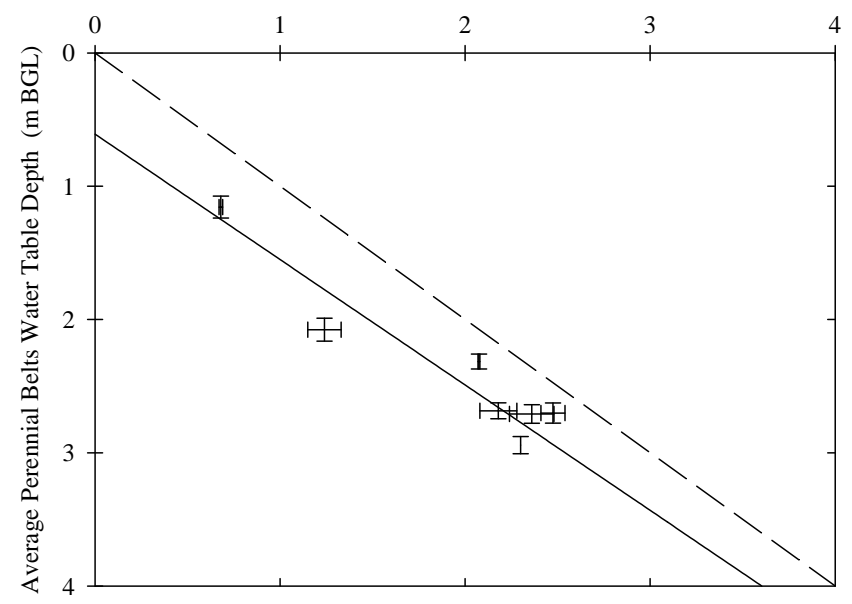

Fig. 4. Correlation between the average water table depth (meters below ground level, mb.g.l.) within the control plots ( \pm standard error, SE) and the perennial tree belts $( \pm$ SE) for the summer minima water table depths over the period 2000 to 2007. Solid line shows the linear regression $\left(r^{2}=0.94\right)$, dashed line represent the $1: 1$ trend line.

Table 3. Sensitivity of perennial belt water use (WU) values, where Sy is the specific yield, $P_{\operatorname{Dev}}$ is the perennial belt deviation from the control piezometers (generated from Fig. 4), and WU is the depth of water transpired by the perennial belt. MIN, MAX, and AV represent the minimum, maximum, and average values for that variable.

\begin{tabular}{ccc}
\hline Sy & $P_{\text {Dev }}$ & WU $(\mathrm{mm})$ \\
\hline MIN & MIN & 3 \\
MIN & AV & 9 \\
MIN & MAX & 15 \\
AV & MIN & 9 \\
AV & AV & 27 \\
AV & MAX & 45 \\
MAX & MIN & 21 \\
MAX & AV & 63 \\
MAX & MAX & 105 \\
\hline
\end{tabular}

the control piezometer level, as shown by the trend line in Fig. 4. Given a site average specific yield of $0.03 \mathrm{~m}^{3} \mathrm{~m}^{-3}$, the $0.9 \mathrm{~m}$ drop in groundwater level corresponds to $27 \mathrm{~mm}$ of additional water use by the perennial tree belts compared to the control. Given the variability of both the specific yields $\left(0.01-0.07 \mathrm{~m}^{3} \mathrm{~m}^{-3}\right.$, with a mean of $\left.0.03 \mathrm{~m}^{3} \mathrm{~m}^{-3}\right)$ observed at the site and the range in water table depths observed in Fig. 4 (0.3-1.5 m b.g.l.), the value attributed to perennial water use will vary considerably across the site (Table 3 ).

Modelling results for the control plot show that after 1996 evapotranspiration was typically equal or slightly greater (average $+3.75 \mathrm{~mm}$ ) than rainfall for every year of the experiment (Table 4).
Table 4. Evaporation loss values generated using a one-dimensional soil water balance model from 1996 to 2007.

\begin{tabular}{ccc}
\hline Year & $\begin{array}{c}\text { Precipitation } \\
(\mathrm{mm})\end{array}$ & $\begin{array}{c}\text { Evapotranspiration } \\
(\mathrm{mm})\end{array}$ \\
\hline 1996 & 361 & 354 \\
1997 & 366 & 381 \\
1998 & 338 & 340 \\
1999 & 404 & 401 \\
2000 & 422 & 425 \\
2001 & 321 & 331 \\
2002 & 261 & 285 \\
2003 & 437 & 424 \\
2004 & 361 & 360 \\
2005 & 343 & 353 \\
2006 & 537 & 524 \\
2007 & 259 & 277 \\
\hline
\end{tabular}

The observed post 2000 decline and stabilisation of the water table height for piezometers within perennial tree belts $\left(B_{\text {belt }}\right)$ and those in the centre of the alley $\left(B_{\text {alley }}\right)$ are shown in Fig. 5. A t-test identified a significant difference in the means of the two locations for January 2001 only $(t=2.97$, $p=0.0046$ ). A Levene's test for homogeneity of variance of the normalised water table data (m b.g.l.) organised by piezometer location (belt or centre of the alley) indicates a significant difference in the variance of the two locations $(F=7.4, p<0.007)$ (Levene, 1960). There is a high correlation between water table depth at $B_{\text {belt }}$ and $B_{\text {alley }}$ from Feb 2000 until June 2002 with an adjusted $r^{2}=0.97, p=0.036$. From June 2003 to July 2007 this trend was no longer statistically significant.

The trend in the average water table depth for $B_{\text {belt }}$ and $B_{\text {alley }}$ for both high and low biomass plots shows that for both locations and treatment design the water tables for the low biomass treatments remained equal to or higher than the water table within the high biomass treatment design. This corresponds well with the water table responses observed for $B_{\text {alley. The difference in average water table depths for } B_{\text {alley }}}$ for treatment design A (low biomass) and F (high biomass) were relatively high at the start of 2000 (Fig. 5). This difference decreases through time; as opposed to the water table trends in $B_{\text {belt }}$ where this difference appears to increase with time.

\subsection{Biomass production}

The biomass data for Eucalyptus vegrandis across the experiment showed that as belt width narrows the biomass increases (Table 5). Biomass increased with belt width from 32 to $4 \mathrm{~m}$, although the difference in biomass between belts of $32 \mathrm{~m}$ and $138 \mathrm{~m}$ width are minor (approximately $2 \mathrm{~kg} \mathrm{~m}^{-2}$ ) at the site. The data displayed a non-linear trend $\left(r^{2}=0.98\right)$ 


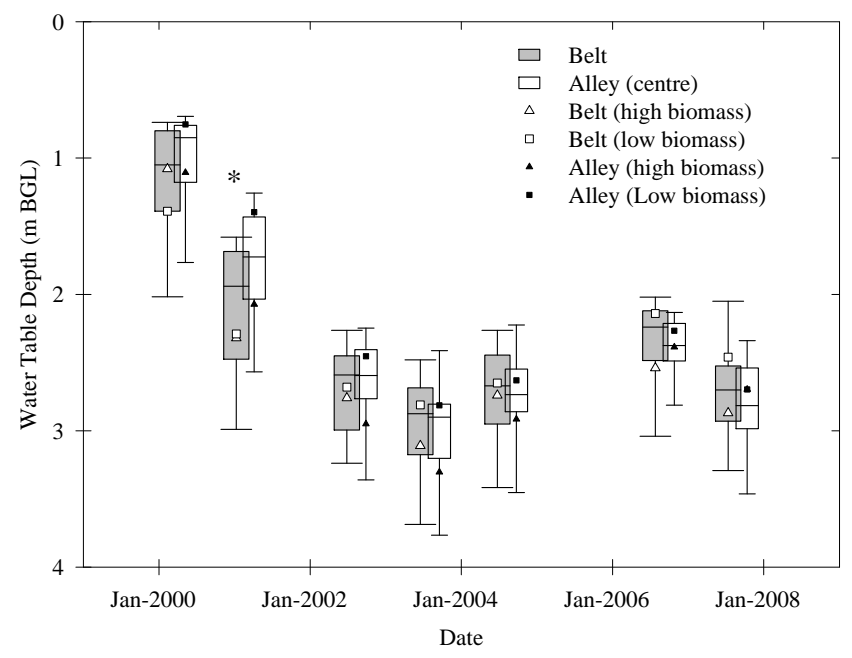

Fig. 5. Box plots of the summer minimum water table depths (meters below ground level) for piezometers within perennial belts (grey box plots) and piezometers located in the centre of the alley (transparent box plots). The boxes represent the mean, 25 percentile, and the 75 percentile. The whiskers indicate the 10 and 90 percentiles. The average water table depth beneath belt (white) and centre of the alley (solid) which produced the largest biomass (triangles, treatment design $\mathrm{F}$ ) and lowest biomass (square, treatment design $\mathrm{G}$ for the belt and $\mathrm{A}$ for the alley) are also indicated. The star identifies the only date on which there was a statistically significant difference in the means of the water table depth between the belt and the alley.

Table 5. Estimates above-ground biomass for 12 year old E. vegrandis for 5 different belt widths.

\begin{tabular}{cc}
\hline Belt Width $\mathrm{m}$ & Biomass $\mathrm{kg} \mathrm{m}^{-2}$ \\
\hline 4 & 37.7 \\
11 & 7.5 \\
18 & 5.2 \\
32 & 3.6 \\
138 & 0.7 \\
\hline
\end{tabular}

which stabilises at mean biomass per $\mathrm{m}^{2}$ of approximately $0.06 \mathrm{~kg} \mathrm{~m}^{-2}$. In terms of maximum biomass production, a double row of trees measuring $4 \mathrm{~m}$ wide would produce the highest above ground biomass whereas block planting (138 $\mathrm{m}$ width) would produce the least.

\section{Discussion}

\subsection{Regional climate trends}

The south west of Western Australia is experiencing a decrease in annual rainfall and an increase in summer rainfall events (Hennessy et al., 1999; Yu and Neil, 1993).
Intense summer rainfall events can be harmful to the environment, and have been linked to an increase in flood frequency, soil erosion, inundation of lowland areas and episodic aquifer recharge (Suppiah and Hennessay, 1998). As a result, recharge events may occur episodically, strongly influenced by rainfall intensity and duration. The impacts of such high rainfall events are evident in the groundwater response to the peak summer rainfall event in 2006. Such out of season events will also negatively impact agricultural production due to soil erosion and loss of soil structure. The redistribution of annual rainfall will reduce agricultural yields and encourage a move towards more sustainable perennial plant options (Connor, 2004; John et al., 2005).

By assuming that the control piezometers are a reflection of climatic trends, a clear deviation and increase in range is observed in water table depths across the site (Fig. 3). Table 2 identifies the limitation of this assumption, for the majority of the experiment water table depths in the control piezometers are less than the minimum water table depth observed in the experiment. It is assumed that placement of the control piezometers is well beyond the influence of the perennial tree belts, however lateral root extension and localised heterogeneity in specific yield and variability in evapotranspiration may account for some of this. The increase in discharge for the average deviation is indicative of the influence of the experiment. The distribution of those piezometers where groundwater levels are shallower than the control piezometers in 2007 may be an indication of the capacity for the belts to redistribute and store groundwater within the unsaturated zone (Burgess et al., 1998). The validity of this relationship is limited by the infrequent monitoring of the experiment and the above average summer rainfall event,

\subsection{Water table fluctuations}

The observed increase in depth to water table has been shown to be driven primarily by rainfall decline rather than by perennial biomass production and hence, plant transpiration. The trend in the control piezometers mimics that of piezometers within belts (Fig. 3), but overall the experiment has lowered the water table by an additional $0.9 \mathrm{~m}$.

Division of the data into piezometers within the perennial belts and those in the centre of the alley (regardless of distance) for the period subsequent to 2000 showed no statistically significant difference in the mean; however the variance was approximately twice as much for piezometers located in the perennial belt (Fig. 5). This difference in the variance of the two locations can be attributed to the effects of lateral root extension from the tree belt. Lateral root extension has been recorded at up $20 \mathrm{~m}$ from the trunk (Ellis et al., 2005 and Zohar, 1985). For treatments with wide alleys $(<30 \mathrm{~m})$ lateral root extension from the belt was observed within piezometers up to $15 \mathrm{~m}$ from the belt edge. This suggests that the response in the water table between $B_{\text {belt }}$ and $B_{\text {alley }}$ within treatment F ( $4 \mathrm{~m}$ belt, $17.5 \mathrm{~m}$ alley, see Fig. 5) would be very 
similar. This is not observed within the data, site variability such as soil structure may be responsible for this limited response.

Site conditions prior to 2000 would have proven detrimental to growth due to the shallow water table promoting water logged conditions that could delay the response in root growth (Barrett-Lennard, 2003, 2002). The quality of the groundwater at the site $(\mathrm{pH}$ ranged between 3 and 5 and electrical conductivity between 22.1 and $45.9 \mathrm{mS} \mathrm{cm}^{-1}$ ) suggests that it may restrict the growth of vertical tap roots. Under such conditions, perennial plant growth rates would be low (Greenwood et al., 1985) and this is reflected in the low biomass recorded at the site. During drought or stress, groundwater may have been accessed as a potential source by perennial vegetation but fresher rainfall derived recharge would be a preferred water source (Archibald et al., 2006). The modelled ET results suggest that the annual rainfall is balanced to evapotranspiration from annual grasses/bare soil (Table 4). The enhancement of ET from the site might have been greater if the transpiration of groundwater by the perennial vegetation was not constrained by poor water quality and by only periodic saturation of the unsaturated (root) zone.

The average water table depth beneath high (treatment design F) and low biomass (treatment design $\mathrm{G}$ ) perennial showed some deviation (Fig. 5) after more than 6 years growth. On average, the water table depths beneath the low biomass belt were shallower than beneath a high biomass belt.

\subsection{Biomass production}

The observed response in the perennial above-ground biomass for the various belt widths was in agreement with observations by Ritson (2004); who showed a similar decline in above-ground biomass production for Pinus pinaster as belt width increased. An increase in competition between individual trees for resources (water, sunlight and nutrients) reduces biomass production and in extreme cases causes plant death. The greater the number of rows of perennial trees in the belts, the greater the competition. This reduction in growth due to competition is greatest in the $100 \%$ revegetation plots at the site (belt width $=138 \mathrm{~m}$ ). All of the $100 \%$ revegetation plots had large numbers of tree deaths, implying severe drought stress. Previous studies have shown that block planting can increase water table depth in areas of good quality groundwater (Harper et al., 2005; Sudmeyer and Goodreid, 2007). Those plots with only 2 rows of trees within the belts produce the highest amount of above-ground biomass. Trees placed on the edge of the belt have a greater opportunity to take advantage of resources from within the alley, providing a biophysical yield advantage over trees planted within the belt (Kho, 2000). Therefore, the aboveground biomass production for treatment design $\mathrm{F}$ (belt width of $4 \mathrm{~m}$, a double row of trees) was highest because both tree rows have the capacity to access resources from within the alley.

\section{Conclusions}

Noorduijn et al. (2009) have shown that the effects of this large scale alley farming experiment contributed to the water table response, and accounted for half of the effect of the regional climate trend. A decline in rainfall over recent years may explain a large proportion of the decline in groundwater levels (approximately $60 \%$ of the variance). Noorduijn et al. (2009) stated that of the remaining $30 \%$ in groundwater variability, the presence and influence of vegetation has contributed significantly.

This study has established that the relative contribution of the experiment, in terms of additional annual water used, is an average of $27 \mathrm{~mm}$ per annum by the perennial tree belts. Lateral root growth by the perennial belt into the alley can account for this additional availability of water. To optimise this water use by the perennial tree belts at the site, a large proportion of land would need to be converted to perennial belts. A narrow perennial belt (approximately $4 \mathrm{~m}$ ) would achieve this and produce the largest biomass providing potential economic returns.

The conceptual model of alley farming, (i.e. deep rooted perennial vegetation create a greater unsaturated zone storage buffer for future large rainfall events (or wet years) and greater store of freshwater) has only marginal relevance at this site due to shallow groundwater having poor quality and restricting vertical root development. This restriction to vertical tap root development (due to shallow groundwater levels (Thorburn et al., 1995, 1993)) and use of groundwater also contributes to the low biomass produced across the site, but has encouraged water use over a wider area due to lateral root development.

Further investigation is required to clearly delineate the impacts of the experiment upon the groundwater table. It is recommended that additional water table and biomass monitoring would greatly increase the understanding of processes at the site. Unsaturated zone moisture monitoring would also be important to understanding water movement. Similarly, sap flow and isotope methods may aid in identifying perennial water sources, and investigation into the root distribution will further explain the observed trends in the water table.

Acknowledgements. Thanks to G. and F. Davenport for allowing access to their land. The authors would like to thank the Department of Environment for access to the TAFT data set and funding for all field work. Special thanks to John Bartle (DEC) and Wayne O' Sullivan for all their help and advise. Saskia Noorduijn acknowledges financial support from the Centre for Groundwater Studies, Centre of Ecohydrology, and the School of Environmental Systems Engineering, The University of Western Australia.

Edited by: G. H. de Rooij 


\section{References}

Archibald, R. D., Harper, R. J., Fox, J. E. D., and Silberstein, R. P.: Tree performance and root-zone salt accumulation in three dryland Australian plantations, Agroforest. Syst., 191-204, 2006.

Asseng, S., Dunin, F. X., Fillery, I. R. P., Tennant, D., and Keating, B. A.: Potential deep drainage under wheat crops in a mediterranean climate. II. Management opportunities to control drainage, Aust. J. Agr. Res., 52, 57-66, 2001a.

Asseng, S., Fillery, I. R. P., Dunin, F. X., Keating, B. A., and Meinke, H.: Potential deep drainage under wheat crops in a mediterranean climate. I. Temporal and spatial variability, Aust. J. Agr. Res., 52, 45-56, $2001 \mathrm{~b}$.

Bari, M. A., Smith, N., Ruprecht, J. K., and Boyd, B. W.: Changes in streamflow components following logging and regeneration in the southern forest of Western Australia, Hydrol. Process., 10, 447-461, 1996.

Barrett-Lennard, E. G.: Restoration of saline land through revegetation, Agr. Water. Manage., 53, 213-226, 2002.

Barrett-Lennard, E. G.: The interaction between waterlogging and salinity in higher plants: Causes, consequences and implications, Plant. Soil., 253, 35-54, 2003.

Bartle, J., Olsen, G., Cooper, D., and Hobbs, T.: Scale of biomass production from new woody crops for salinity control in dryland agriculture in Australia, Int. J. Global. Energy., 27, 115137, 2007.

Bell, T. D. and Froend, R. H.: Mortality and growth of tree species under stress at Lake Toolibin in the Western Australian wheatbelt, Journal of the Royal Society of Western Australia, 72, 6366, 1990.

Bird, P. R., Bicknell, D., Bulman, P. A., Burke, S. J. A., Leys, J. F., Parker, J. N., Sommen, F. J., and Voller, P.: The role of shelter in Australia for protecting soils, plants and livestock, Agroforest. Syst. 20, 59-86, 1992.

Burgess, S. S. O., Adams, M. A., Turner, N. C., and Ong, C. K.: The redistribution of soil water by tree root systems, Oecologia, 115, 306-311, 1998.

Clarke, C. J., Bell, R. W., Hobbs, R. J., and George, R. J.: Incorporating geological effects in modelling of revegetation strategies for salt-affected landscape, Environ. Manage., 24, 99-109, 1999.

Clarke, C. J., George, R. J., Bell, R. W., and Hatton, T. J.: Dryland salinity in south-Western Australia: Its origins, remedies, and future research directions, Aust. J. Soil. Res., 40, 93-113, 2002.

Connor, D. J.: Designing cropping systems for efficient use of limited water in southern Australia, Eur. J. Agron., 21, 419-431, 2004.

Cooper, D., Olsen, G., and Bartle, J.: Capture of agricultural surplus water determines the productivity and scale of new low-rainfall woody crop industries, Aust. J. Exp. Agr., 45, 1369-1388, 2005.

Cramer, V. A. and Hobbs, R. J.: Ecological consequences of altered hydrological regimes in fragmented ecosystems in southern Australia: Impacts and possible management responses, Austral. Ecol., 27, 546-564, 2002.

Droppelmann, K. and Berliner, P.: Runoff agroforestry-a technique to secure the livelihood of pastoralists in the middle east, J. Arid. Environ., 54, 571-577, 2003.

Eastham, J. and Gregory, P. J.: Deriving empirical models of evaporation from soil beneath crops in a mediterranean climate using microlysimetry, Aust. J. Agr. Res., 51, 1017-1022, 2000.

Ellis, T., Hatton, T., and Nuberg, I.: An ecological optimality ap- proach for predicting deep drainage from tree belts of alley farms in water-limited environments, Agr. Water. Manage., 75, 92-116, 2005.

Ellis, T. W., Leguedois, S., Hairsine, P. B., and Tongway, D. J.: Capture of overland flow by a tree belt on a pastured hillslope in south-eastern Australia, Aust. J. Soil. Res., 44, 117-125, 2006.

Global network on integrated soil management for sustainable use of salt-affected soils: http://www.fao.org/ag/agl/agll/spush/ topic2.htm, 2009.

Ferdowsian, R., George, R., Lewis, M. F., McFarlane, D. J., Short, R., and Speed, R.: The extent of dryland salinity in Western Australia, 4th National Conference and Workshop on the Productive Use and Rehabilitation of Saline Lands, Albany, Western Australia, 89-97, 1996.

George, R. J., McFarlane, D. J., and Lewis, M. F.: A review of recharge and implications for management in saline agricultural catchments, Western Australia, Proceedings of the International Hydrology and Water Resource Symposium, Perth, 193-197, 1991.

George, R. J.: Hydraulic properties of groundwater systems in the saprolite and sediments of the wheatbelt, Western Australia, J. Hydrol., 130, 251-278, 1992.

George, R. J., McFarlane, D. J., and Nulsen, R. A.: Salinity threatens the viability of agriculture and ecosystems in Western Australia, Hydrogeol. J., 5, 6-21, 1997.

George, R. and Bennett, D.: Airborne geophysics provided improves spatial information for the managementof dryland salinity, in: Land degradation, edited by: Conacher, A., Kluwer Academic Publishers, 305-318, 2001.

Greenwood, E. A. N., Klein, L., Beresford, J. D., and Watson, G. D.: Difference in annual evaporation between grazed pasture and Eucalyptus species in plantations on a saline farm catchment, J. Hydrol., Vol. 78, 261-278, 1985.

Harper, R. J., Robinson, N., Smettem, K. R. J., and Sochacki, S.: Phase farming with trees: The acceleration of farm forestry to combat dryland salinity, Int. For. Rev., 7, 276-277, 2005.

Harper, R. J., Beck, A. C., Ritson, P., Hill, M. J., Mitchell, C. D., Barrett, D. J., Smettem, K. R. J., and Mann, S. S.: The potential of greenhouse sinks to underwrite improved land management, Ecol. Eng., 29, 329-341, 2007.

Hatton, T. J., Ruprecht, J., and George, R. J.: Preclearing hydrology of the Western Australia wheatbelt: Target for the future?, Plant Soil, 257, 341-356, 2003.

Hennessy, K. J., Suppiah, R., and Page, C. M.: Australian rainfall changes, 1910-1995, Aust. Meteorol. Mag., 48, 1-13, 1999.

John, M., Pannell, D., and Kingwell, R.: Climate change and the economics of farm management in the face of land degradation: Dryland salinity in Western Australia, Can. J. Agr. Econ., Vol. 53, 443-459, 2005.

Kang, B. T., Wilson, G. F., and Lawson, T. L.: Alley farming: A stable alternative to shifting cultivation, International Institute of Tropical Agriculture, Ibadan, Nigeria, 1984.

Kareiva, P. and Marvier, M.: Conserving biodiversity coldspots, Am. Sci., 91, 344-351, 2003.

Kho, R. M.: A general tree-environment-crop interaction equation for predictive understanding of agroforestry systems, Agr. Ecosyst. Environ., 80, 87-100, 2000.

Langford, K. J.: Change in yield of water following a bushfire in a forest of Eucalyptus Regnans, J. Hydrol., 29, 87-114, 1976. 
Lefroy, E. C. and Stirzaker, R. J.: Agroforestry for water management in the cropping zone of southern Australia, Agroforest. Syst., 45, 277-302, 1999.

Lefroy, E. C., Flugge, F., Avery, A., and Hume, I.: Potential of current perennial plant-based farming systems to deliver salinity management outcomes and improve prospects for native biodiversity: A review, Aust. J. Exp. Agr., 45, 1357-1367, 2005.

Levene, H.: Robust tests for equality variance, in: Contributions to probability and statistics: Essays in honor of Harold Hotelling, edited by: Olkin, I., Ghurye, S. G., Hoeffding, W., Madow, W. G., and Mann, H. B., Stanford University Press, Stanford, CA, 278-292, 1960.

Mooris, D. A. and Johnson, A. I.: Summary of hydrological and physical properties of rock and soil material as analyzed by the hydrological laboratory of the US Geological survey, USGS Supply Paper: 1839-D, 1967.

National Land and Water Resources Audit: Australian dryland salinity assessment 2000, Extent, impacts, processes, monitoring and management options, in Land and Water Australia, Canberra, 2001.

Noorduijn, S. L., Ghadouani, A., Vogwill, R., and Smettem, K.: Response of the water table to an experimental alley farming experiment: Dissecting the spatial and temporal structure of the data, Ecol. Appl., in press., 2009.

Nulsen, R. A.: Evapotranspiration of four major agricultural plant communities in the south-west of Western Australia measured with large ventilated chambers, Agr. Water. Manage., 8, 191202, 1984.

Nulsen, R. A. and Baxter, I. N.: Water use by some crops and pastures in the southern agricultural areas of Western Australia, Department of Agriculture, Resource Management Technical Report No. 32, http://www.agric.wa.gov.au/objtwr/imported_assets/ content/_archive/tr032.pdf, 1986.

Ogunlana, E. A., Salokhe, V., and Ranghild, L.: Alley farming: A sustainable technology for crops and livestock production, J. Sustain. Agr., 29, 131-144, 2006.

Oliver, Y. M., Lefroy, E. C., Stirzaker, R. J., and Davies, C. L.: Deep-drainage control and yield: The trade-off between trees and crops in agroforestry systems in the medium to low rainfall area of Australia, Aust. J. Agr. Res., 1011-1026, 2005.

Ritson, P.: Growth, yield and carbon sequestration of Pinus pinaster established on farmland in south-Western Australia, PhD Institute of Land and Food Resources, University of Melbourne, Melbourne, 2004.
Ruprecht, J. K. and Stoneman, G. L.: Water yield issues in the jarrah forest of south-Western Australia, J. Hydrol., 150, 369-391, 1993.

Salama, R. B., Farrington, P., Bartle, G. A., and Watson, G. D.: Identification of recharge and discharge areas in the wheatbelt of Western Australia using water level patterns in relation to basin geomorphology, International Hydrology and Water Resources Symposium, Perth, Western Australia, 841-846, 1991.

Scott, P. R. and Sudmeyer, R. A.: Evapotranspiration from agricultural plant communities in the high rainfall zone of the southwest of Western Australia, J. Hydrol., 146, 301-319, 1993.

Smith, I. N., McIntosh, P., Ansell, T. J., and McInnes, K.: Southwest Western Australian winter rainfall and its association with Indian Ocean climate variability, Int. J. Climatol., 20, 19131930, 2000.

Sudmeyer, R. A. and Goodreid, A.: Short rotation woody crops: A prospective method for phytoremediation of agricultural land at risk of salinisation in southern Australia?, Ecol. Eng., 29, 350361, 2007.

Suppiah, R. and Hennessay, K., J: Trends in total rainfall, heavy rain events and number of dry days in Australia, 1910-1990, Int. J. Climatol., 10, 1141-1164, 1998.

Thorburn, P. J., Hatton, T., and Walker, G. R.: Combining measurements of transpiration and stable isotopes of water to determine groundwater discharge from forests, J. Hydrol., Vol. 150, 563587, 1993.

Thorburn, P. J., Walker, G. R., and Jolly, I. D.: Uptake of saline groundwater by plants: An analytical model for semi-arid and arid areas, Plant Soil, Vol. 177, 1-11, 1995.

White, D. A., Dunin, F. X., Turner, N. C., Ward, B. H., and Galbraith, J. H.: Water use by contour-planted belts of trees comprised of four Eucalyptus species, Agr. Water. Manage., 53, 133152, 2002.

Wildy, D. T. and Pate, J. S.: Quantifying above- and below-ground growth responses of the Western Australian oil mallee, Eucalyptus kochii subsp. Plenissima, to contrasting decapitation regimes, Ann. Bot-London., 90, 185-197, doi:10.1093/aob/mcf166, 2002.

Yu, B. and Neil, D. T.: Long-term variations in regional rainfall in the south-west of Western Australia and the difference between average and high intensity rainfall, Int. J. Climatol., Vol. 13, 7788, 1993.

Zohar, Y.: Root distribution of a eucalypt shelterbelt, Forest. Ecol. Manag., 12, 305-307, 1985. 